\title{
決定臟器吸収線量測定用ガラス線量計
}

\author{
横 田 良 助*, 武 藤 雄 平* \\ 直 井 次 郎**, 西島 俊 二**
}

(1968年9月6日 受理)

\section{Glass Dosimeter for Measuring the Apsorped \\ Dose in Critical Orgons}

by Ryosuke Yokota, Yuhei Muto. Jiro Naoi and Shunji Nishijima

\begin{abstract}
Glass dosimeter developed by Piesch for measuring the absorbed dose in critical organs, in which only one FD-P8-1 glass was encased in asuitable badge case, was examined for the case of FD-3 glass, FGD-6 type Fluorimeter, standard Japanese man phantom, and a badge case manufactured by us.

This experiment confirmed the same validity for this case as well as the case of FD-1 glass, FGD-3B type Fluorimeter and Alderson man phantom which were used used by Piesch.

The merits of this glass dosimeter against other dosimeters are discussed from the view point of the personnel dosimetry for radiation protection.
\end{abstract}

\section{1 まえが}

周知のよ5に ICRP 铺告1)では最大許容年稓算線量が 決定贜器の dose equivalent で表現されている。従っ て,放射線防揽のための個人被曝線量計は単に exposure のみでなく, 決定脸器の dose equivalent が必要に応し て測定されるか, 又は評価されなければならない。ここ で”必要に応じ“の必要とは低レベル被懪のときでない ことは勿論である。

外部被曝の場合に, むし個人被曝線量計がたんに exposure のみを揤定するだけであって，決定䑏器の dose equivalent が評価しえないならば，ICRP 衡告はその技 術的有効性に乏しくなる。

ここでは問題を電磁放射線（即ち， $\gamma$ 線，X線）に限 ることにする。すると個人被曝線量計によって決定䑏器 の吸収線量が rad で則定されるか又は評価されなければ ならない。そしてその方法は出来るたけ簢でコストの 少ないことが梗めて望ましい。

$\gamma$ 線又はX線のエネルギースペクトルと入射方向がか かれば，胸につけた exposure を測定する線䡒計で決定 臟器吸収線量が評価され5る。何故ならばファントムに よる実験で各エネルギーと入射方向に対するdepth-dose 曲線がすでに求められているからである。

フィルム線量計に対する評価柱一されていないか，
フィルム線量計では放射線のエネルギースペクトルとス 射方向が求められ, 従って決定腧器吸収線量が評価され らるといら意見すある。2)しかしフフィルム線量計は方 向依存性が相当あり，制に 60〜130kev 領域でこれが著 しいので，実際使用下ではェネルギースベクトルは相当 不正確なるのとなり，また入射方向も正しく求められな いことが多い。放射線測定ENEAシンボシゥム（1967 年, ストックホルム) でも批判が多かった。3）従って㬰 際使用下でのフィルム線量計の決定搭器吸収線量評価機 能は大いに最わしいといってよいであろう。

Piesch と Maushart はガラス線量計を用いて, 球形 カブセルを適当に選ぶと，たった一個のガラスで各決定 䑏器の吸收線量がさ15\%の精度で求まることを示した。 その適用ェネルギー簀囲は45〜50kevより $1.25 \mathrm{Mev}$ まで である。彼等は横田ら4)が開発した線量計ガラス (FD1 ガラス）と FGD- 3 B 形測定器を用いた。

現在の改良された標溄の测定器は FGD- 6 形で，光学 系が FGD-3B形とことなり，線㗐計ガラスに対する刺戟 紫外線の入射方向やセルの形状もちがらので，果して，

* 東艺中央研究所 (Central Research Labovatory, Tokyo Shibaura Eleetric Co)

** 電気試験所田無分室 (Electrotechnical Labovatory, Tanashi Branch) 
FGD-3B 形と同様な結果が得られるかどらか，又線 計ガラスも進歩してFD-3ガラスとなり，エネルギー依 存性す㮖かであるかFP- 1 ガラスとことなるので標柒の 日本人の寸法のフフントムで実験して Piesch らの方法 が同様にあてはまるかどらか碓める必要が生じたので実 験して確めることができた。

\section{2 各㵂器收吸線贯のエネルギー传存性}

以下に必要のために, A. R. Jones, Facey, Piesch 5 が求めた結果を简単にのべる。

(1) A.R. Jones5) はフフントムを用いて非常に精密な 実験をした。各䑏器に LiF䍭ルミネッセンス線量計を埋 めこんだ。曝射した各実奻值の $\gamma$ 線又はX線はそのエネ ルギースベクトルが充分鋭いるのであって，その結果は 充分信用しらるすのである。表 1 に A. R. Jonrs が LiF 線量計を Alderson フフントムにうめこんだ各䑏器の位 置を示す。赤色骨蹃は身体全体，特に胴火多く分布して いるので夫々に5めこんた。。夫ゃの赤色骨蹃に夫々の重 量分害をかけて平均した平均赤色骨䯣吸収線量を求め た。

問題となる膵器は身体内部の注ぼ中央にある平均骨䯣 と卵巣の一群之, 男子生殖腺, 皮应, 水晶体, 胃渴管粘 膜の身体表面や表面下 $2 \mathrm{~cm}$ 以内にある一群との二つの

Table 1.

The positions of the various organs ints which dosimeters are implanted. (by A. R Jones)

\begin{tabular}{|c|c|c|c|}
\hline No & organ & \begin{tabular}{|c} 
distance from \\
front surface \\
$(\mathrm{cm})$
\end{tabular} & $\begin{array}{l}\text { distance from } \\
\text { back surface } \\
\text { (cm) }\end{array}$ \\
\hline 1 & brain & 3 & 16 \\
\hline $2 *$ & cramium marrow & 18 & 2 \\
\hline $3 * s$ & stermum marrow & 2 & 20 \\
\hline $4^{*} s$ & scapula marrow & 12 & 4 \\
\hline $5 *$ & $\begin{array}{l}\text { sixth thoracic } \\
\text { vertebra marrow }\end{array}$ & 15 & 7 \\
\hline $6 * 2$ & $\begin{array}{l}\text { 2nd lumbar vertebra } \\
\text { marrow }\end{array}$ & 13 & 8 \\
\hline $7 * s$ & scarum marrow & 15 & 7 \\
\hline $8^{*}$ & iliac crest marrow & 8 & 12 \\
\hline 90 & ovarics & 10 & 11 \\
\hline 10 e & eye lens & 0.5 & 18 \\
\hline $11 \mathrm{t}$ & testes & 2 & indeterminate \\
\hline $12 \mathrm{~s}$ & skin (forehand) & 0 & 20 \\
\hline $13 \mathrm{~s}$ & $\operatorname{skin}$ (at chest) & 0 & 22 \\
\hline $14 \mathrm{~s}$ & skin (at back chest) & 22 & 0 \\
\hline
\end{tabular}

* From No. 2, 3, 4, 5, 6, 7 and 8 weighted average bone marrow is obtained.
群に分れる。

15才から35才までの年令による身体寸法の差は少な い。潔の人間を考学ると平均の寸法の $\pm 20 \%$ 以内に 90 \%の人が入る。平均の寸法から士20\%ちがっても, 各決 定膙器の吸収線量の変化は少ない。5) A.R.Jones はフ ントムの前面より，また背面より，また迴転させて曝射 した。

$1 \mathrm{R}$ 瀑射したとき，どれだけのェネルギーが各腀器に 吸収されるかを，27kev より $1.25 \mathrm{Mev}$ のネルギー領 域で各ェネルギーに対して求めだ。

因 1 は正面爆射のるので, 綎軸は $\mathrm{rad} / \mathrm{R}$, 横軸はエネ ルギーである。図1を見ると，平均赤色骨蹃と卵巣の吸 収線贯のエネルギー传存性は驚く汪どー致している。ま た，水晶体，男子生殖腺，胃渴管粘膜，皮庙の吸収線量 のエネルギー体存性曲線は比較的よく似ている。水晶 体, 男子生殖線は表面より夫々 $0.5 \mathrm{~cm}$ ，および $2 \mathrm{~cm}$ 奥 にあり，胃晹管る比較的表面近くにあるので夫々の臟器 の吸收線量のエネルギー依存性曲線る互いに似ているの である。60〜130kev 領域での吸収線贵が 60Co 7 線等の 高エネルギー領域より著しく大きくなっているのは，身 体による後方散乱がこのエネルギー笧团で著しく增加す るからである。

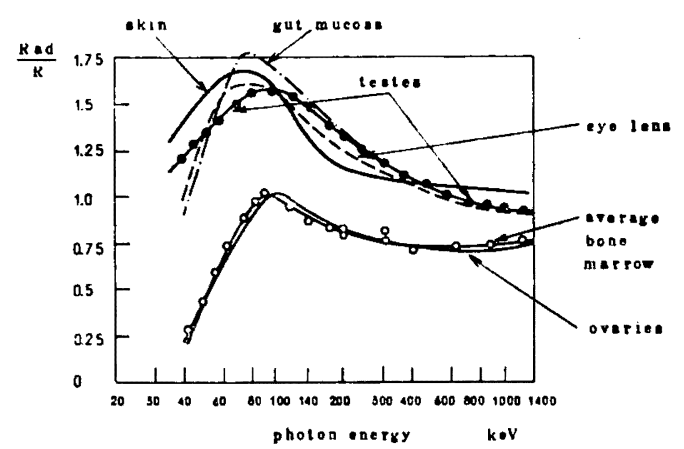

Fig. 1. Absorded bose in various organs as a function of photon energy referred to an exposure of $1 \mathrm{R}$ in the case of frontal irradiation (after A. R. Jones).

重要なことは，正面爆射のときに得られた図 1 の関係 は，前面でありさえすればその入射方向に殊んどよらな いことである。即ち真横からの入射をのぞいたすへての 前面入射に対して第一近似で成立するのである。

(2) 四2はフナントムを回転して儤射したときである。 全部の被曝が散乱線のときに相当する。平均赤色骨蹃は 全身に分布しているので吸收線量に方向依存性は殆んど ない。卵巣は身体の注ば中央にあるので殆んど方向によ らない。身体前面にある水晶体，男子生殖腺や胃腸管粘 


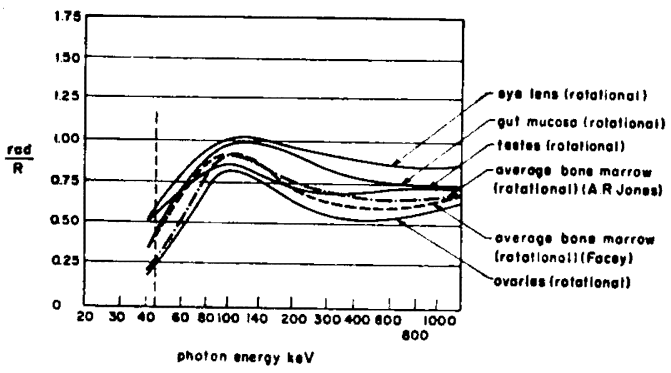

Fig. 2. Absorbed dose in various organs as a function of photon energy referred to an exposure of $1 R$ in the case of rotational irradiation (after A. R. Jones and Facey). chain line......average bone marrow (rotational) after Facey

broken line...average bone marrow (rotational) after A. R. Jones.

膜は背面からの被㛭に対しては吸収線吾は当然少ない。 従って,フナントムを回転して曝射したときは, 赤色骨 噵, 卵策, 皮成, 水晶体, 男子生殖腺中胃渴管粘獏は土 25\%の筑用内で同一のエネルギー依存性の曲線を持つこ とがわかる。

骨㖪内では線貿が骨のために少し硬くなる。Facey6) は土ネルギー依存性のことなる 2 種の TLD 即ち LiF と $\mathrm{CaSO}_{4}: \mathrm{Sm}$ を一対として用いて赛晾し， A. R. Jones の 赤色骨面吸収線量のエネルギー依存性曲線を㚝正した。 これを図2の鎖線に示した。しかしこの售正によって

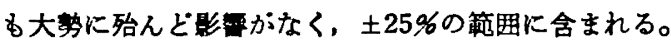
他の满器に対しては监正の必要がなかった。即ち、フォ ントムを回転して曝射したときの各腀器の吸収線五は正 面曝射のときの平均赤色骨髄の吸収線量のエネルギー依 存性曲線に近いのである。

（3）個人被曝線量計は身体表面に装置されていて，乙 かも必要な臓器吸収線五が测定できる必要がある。実腙 には作菜者は衣服をつけているのであるから，個人被曝 楾量計は裸のフォントムから $1 \mathrm{~cm}$ 前の部位にある。する と, 身体の後方散乱をらける度合いが変化し，この変化 は60〜130kev領域では大きくその他の領域では少ない。 Piesch7) はこの点に着目して, Aldersonフォントムの前 $1 \mathrm{~cm}$ ところの吸収線最を男子生殖腺について求めた。 実験は，A. R. Jones と同しく、フフルターを充分強く してェネルギースベクトルの巾を充分狭くしたX線を照 射して正面暴射に対して求めたるので充分信用できるる のである。図3に揭げた。各腧器の吸収線量のエネルギ 一依存性を正面曝射に対して図 4 に示した。たたし平均 赤色骨蹃のみは背面からの曝射のときをとった。背面か

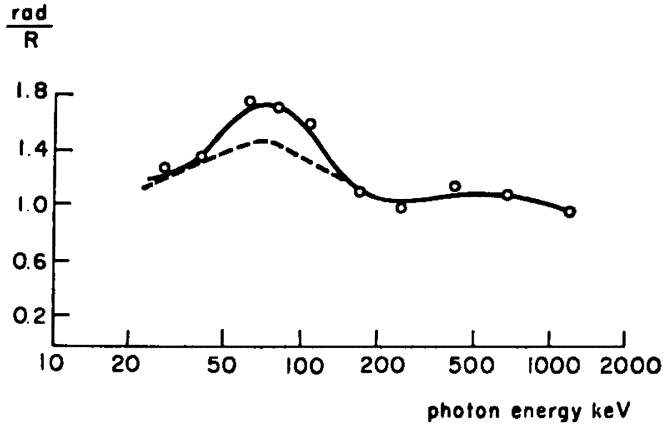

Fig. 3. Absorbed dose in testes as a function of photon energy referred to an exposure of 1 $R$ in the case of frontal irradiation (after E. Piesch).
at phantom surface
....... $1 \mathrm{~cm}$ from phantom surface

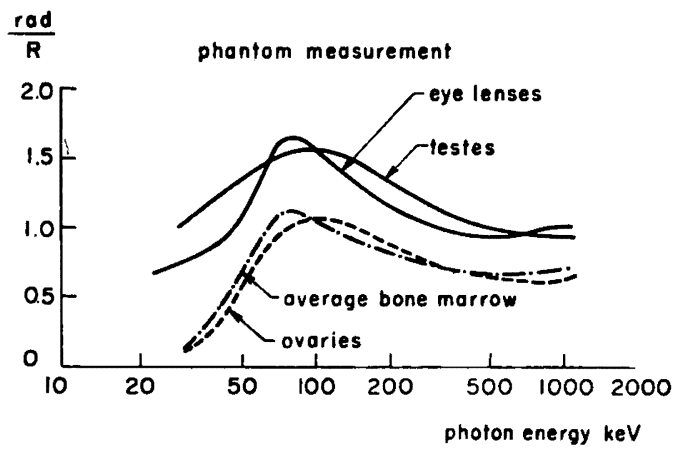

Fig. 4. Absorbed dose in various as a function of photon energy referred to an exposure of 1 $\mathrm{R}$ of an Alderson man phantom in the case of frontal irradiation (after E. Piesch).

らの方が僅かに吸収線影が大である。図4で大事なこと は，（45～50） kev〜1.2MeV 領域では，男子生殖腺の エネルギー侬存性の曲線の形は赤色骨髄や卵巣のそれに よく似ており，男子生殖腺のそれの1/1.5が平均赤色骨领 や卵宩のそれはほぼ等しいことである。

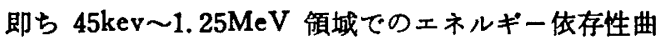
線が因 4 の平均赤色骨噵のそれに近い個人被曝線量計が あり，しかも方向依存性が実際上䈍視できるならば,こ れによってすへての臟器吸収楾量が求められる。

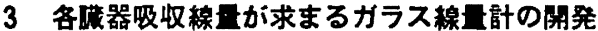

Maushart と Piesch8) は東芝ガラスFD-P 8-1（8X $8 \times 4.7 \mathrm{~mm}$ ) を用い, Sn $1.2 \mathrm{~mm}$ 厚の球形カブセルをか ぶせた。Snカブセルの $20 \%$ に相当する面䖽に $120^{\circ}$ のテ 一ハのついた穴があり，Sn カブセルとガラスとの間に 


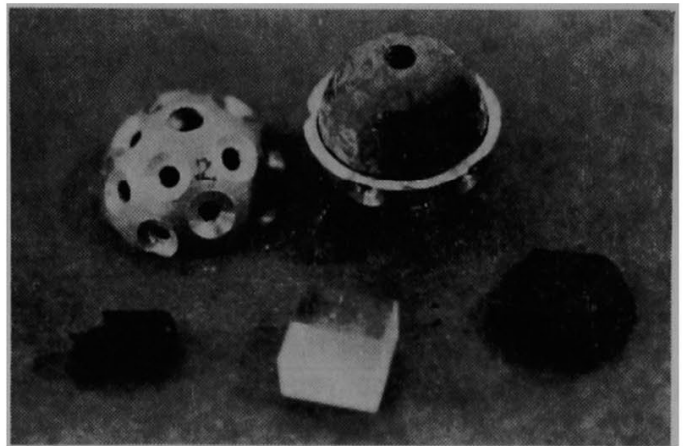

Fig. 5. New spherical capsule badge case for the absorbed dose measurement of critical organs and FD- 3 dosimeter glass $(8 \times 3 \times 4.7$ $\mathrm{mm}^{\mathbf{3}}$ ).

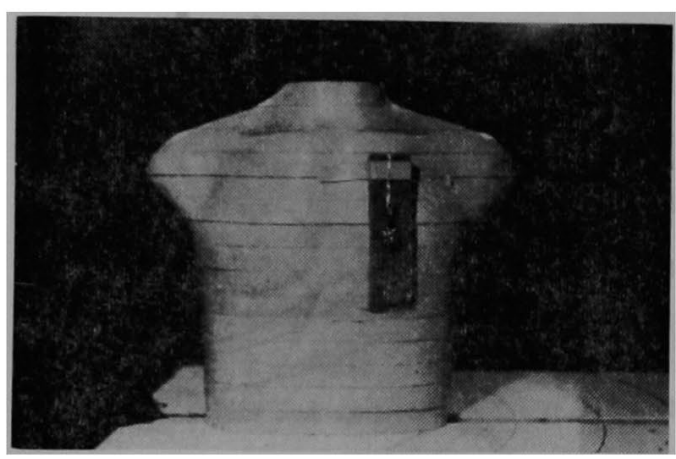

Fig. 6. New spherical capsule badge case for critical organs at $1 \mathrm{~cm}$ apart from the chest of Japanese standard man phantom.

は15mm $\phi$ の球形のペークライトがある。方向依存性は 実用上無視できる。我々も同じものを試作した。図 5 の 写真が試作したものである。現在の改良された FGD-6 形測定器では線量計ガラスに対する励起紫外線の入射方 向が FGD-3B 形のそれとことなるのと，FD-3線量計ガ ラスはFD- 1 ガラスと較ぺて僅かにェネルギー依存性が 良くなっているので, Maushart とPieschが前述の球形 カブセルハッチケースに入れたFD- 1 ガラスと FGD-3 B形测定器と Alderson フフントムで成功したけれども 〔FGD- 6 形測定器+FD-3ガラス十試作ハッッチース 十標準日本人ファントム〕の組合せが目的に合って同じ く成立するかどらか実験によってたしかめる必要があ る。日本人の標準人の寸法のフフントムを用いて,ファ ントムの左胸に試作バッチケースをつけて，電気試験所 において，曝射X線のェネルギー幅をできるだけ狭くす るよらにフイルタを強くして曝射した。衣服をつけたこ とに相当して，厚さ $1 \mathrm{~cm}$ のスボンジム゙板をつけて， その上にガラスを入れた試作バッチケースをつけた。因

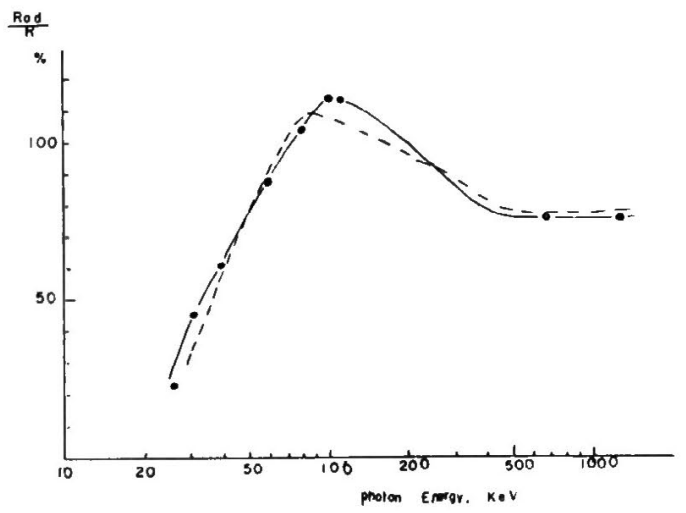

Fig. 7. Response of new spherical capsimeter by 1.6 as a function of photon energy in the case of FGD- 3 B type Fluorimeter.

new spherical capsule dosimeter resimeter response divided by 1.6 absorbed dose of an average bone marrow

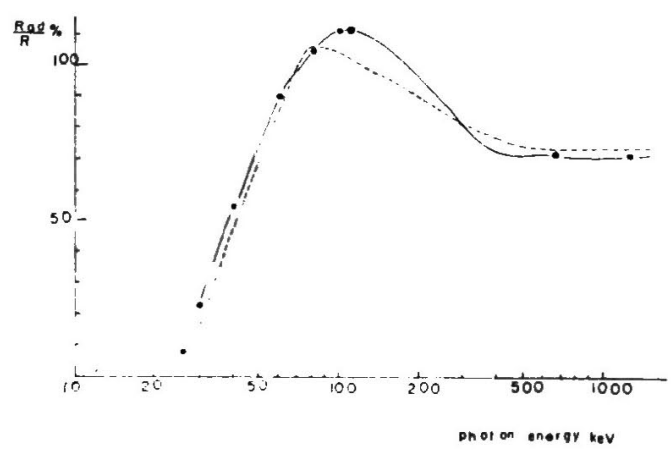

Fig. 8. Response of new spherical capsule dosimeter divided by 1.6 as a function energy in the case of FGD- 6 type Fluorimeter.

- new spherical capsule dosimeter response divided by 1.6

absorbed dose of an avdrage bone marrow

6 に示した。

ここで，方向依存性をよくするための線量計ガラスの 配㯰は FGD- 3 B形と 6 形とではことなり, 前者では 8

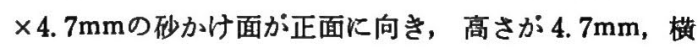
幅が $8 \mathrm{~mm}$ の状態である。後者では前者のときの配㯰を そのまま $180^{\circ}$ 迴転した位置が良いことがかかった。線量 計ガラスFD- 3 をこのよ5に配㯰したときに得られるエ ネルギー依存性曲線をFGD-3 B形, FGD- 6 形について 夫々図7，8に示す。ただ図の実線は $\mathrm{rad} / \mathrm{R}$ で求め た（ここで rad は男子生殖腺の rad である）個人被曝 
線五計のよみに $1 / 1.0$ をかけたのである。又図には点線 で平均赤色骨鸰の吸収線豆のエネルギー依存性曲線（図 4 のむの)を示した。

この実臨によって炊の三つのことがわかった。(1)試作 ハッチケースは目的に合っている。(2)線早計ガラスは FD- 1 ガラスでも FD- 3 ガラスでも実用上同じに目的 を達する。(3)線量計ガラスの配酎をハッチケース内でか えれば FGD-3 B形と6 形との測定器による違いは実際 上無視できる。

フフントムを回転して曝射したときは，新しいガラス 楾量計のよみは因 2 の男子生殖腺のレスボンスに近いレ スボンスを示すことは碓実である。従って,このときは, 土25\%の籍囲で平均赤色骨蹃, 卵栄, 胃軥管粘膜, 水晶 体, 男子生殖腺の吸収線旦を与える。・

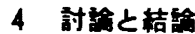

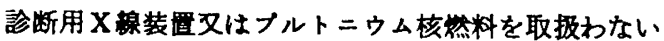
ところ, 即ち ${ }^{60} \mathrm{Co},{ }^{187} \mathrm{Cs}$ 等の $\gamma$ 線源を取扱らところゃ 原子力成俰では，取す低いェネルギーの散乱線です 45 kev以上であり，45kev以下のるのは無視できる。

従ってこのよ5な慗莱所ではこの新しい線量計があて はまる。この方法の特圂は简でニストがかからずに各 臟器の吸収線旦が出せるといらことである。

一般に作羓者は線源に向って仕事をし，男子生殖腺， 胃腸管粘膜, 水晶体の器は身体前面部にあるから, 前 面曝射に対して男子生殖腺の吸収線量で茂正してあるこ のガラス線吾計のよみは ”安全側“にあるといえる。そ して前面ならば $\pm 80^{\circ}$ の入射方向に対して適用できる。 なおこの線量計は $20 \mathrm{~mm}$ 厚の軟組乘でおおわれた男子 生殖腺の吸収線量を示すよらに茂正されており，45kev 〜1. 25Mev のエネルギー領城でいえば，図4で見るよ らに後方散乱の影箱をとり入れた本ガラス楾是計は，前 面曝射に対して，後方散乱をとりのぞいた表面線量を湘 定している我が国における現行のフィルム線量計のレス ボンスより大である。即ちこの新しいガラス線量計の方 がフィルム線早計よりる前面曝射に対して“安全側“に
ある。

結論として, FGD- 6 形又は 3 B 形測定器と, 試作ハ ッチケースと標牶ガラスFD- 3 ガラスを用いて，標染日 本人の寸法のフフントムの胸に $1 \mathrm{~cm}$ はなしたところに おいて，正面から暚射し，そのレスボンスを男子生殖腺 の吸収線量で較正しておけば， その值は 45kev〜1.25 Mevのエネルギー䇥囲で，正面に対して $\pm 80^{\circ}$ の入射方 向に対して，エネルギーに関係なく即ちエネルギーを求 める必要なく，男子生殖腺の吸収線骨を与える。これは 又，水晶体，胃腸管粘膜，皮成の吸収線量をも土5\%以 内であたえる。この線至計のよみを1/1.6倍すれば平均赤 色骨髄と贸策の吸収線些が得られる。

ガラス線䡒計が再测定可能でそのまま年秷算線旦が求 まるのと，良い精度や特性や低いコストと結びついて， 放射線防護のための個人被曝線丝計として，今までの個 人被曝線貄よりもよりよい線亚計であるといえよう。

\section{考文献}

1) Recommendations of the ICRP Publication 9, Pergamon press, Oxford (1965)

2) H. J. Delafield, Phys. Med. Biol. 11, 63(1966)

3) E. Piesch, "Radiation Dose measurements", ENEA symposium, Stockholm, 1967, p. 151-170.

4) R. Yokota, S. Nakajima and H. Sakai, Health phys., 5, 219 (1961) ; R. Yokota, S. Nakajima and H. Osawa, Toshiba Review (Oversea Edition) Spring, p. 41 (1962); R. Yokota, and S. Nakajima, Health Phys 11, 241 (1965) ; R. Yokota and S. Nakajima, Int. Conf. Lum. Dosimetry, Stanford, 1965

5) A. R. Jones, AECL-2240 ; Health Phys 12, 663 (1963)

6) R. A. Facey, Health Phys. 14, 557 (1968)

7) E. Piesch, Health Phys. 13, 759 (1967)

8) R. Maushart und E. Piesch, 1st Int. Cong. Rad. Protection, Rome, 1966 